\title{
Manejo de Plantas Daninhas na Cultura do Tomateiro ${ }^{1}$
}

\author{
Weed Management in Tomato
}

\begin{abstract}
RONCHI, C.P. ${ }^{2}$, SERRANO, L.A.L. ${ }^{3}$, SILVA. A.A. ${ }^{4}$ e GUIMARÃES, O.R. ${ }^{5}$
RESUMO - O tomate (Lycopersicon esculentum) é a segunda hortaliça em importância no Brasil. O controle de plantas daninhas na cultura representa um dos principais componentes do custo de produção, sendo imprescindivel para a obtenção de produtividades elevadas e de frutos de qualidade. Neste texto são apresentados de forma detalhada os efeitos adversos da interferência das plantas daninhas sobre a cultura, tanto daquele cultivado a partir de mudas transplantadas como de semeadura direta. Também são discutidos, para diferentes situações de cultivo, aspectos sobre o período crítico de competição das plantas daninhas durante o ciclo da cultura. Por fim, são apresentadas as principais estratégias utilizadas para o controle de plantas daninhas na cultura do tomateiro, por meio de medidas preventivas, culturais, mecânicas e químicas, com base nas informações atualmente disponiveis sobre esse tema.
\end{abstract}

Palavras-chave: Lycopersicon esculentum, herbicidas, manejo integrado, seletividade, período de competição.

\begin{abstract}
Tomato (Lycopersicon esculentum) is the second most important vegetable grown in Brazil. Weed control in tomato culture is one of the main components in crop production costs. However, weed management is indispensable to achieve both high yields and fruit quality. A detailed discussion is presented in this work concerning the adverse effects of weed interference in the crop, both grown from transplanted seedlings and field-sown tomato. Aspects related to the critical period of weed competition during the crop cycle for both growing conditions are also discussed. Finally, the major strategies used for weed management in tomato crops are also presented, such as preventive, cultural, mechanic, and chemical control measures, based on the literature currently available.
\end{abstract}

Keywords: Lycopersicon esculentum, herbicides, integrated management, selectivity, weedy period.

\section{INTRODUÇÃO}

O tomate (Lycopersicon esculentum) é a segunda hortaliça em importância no Brasil. Em 2008, o País produziu 3,9 milhões de toneladas em 62 mil hectares (IBGE, 2009), fato que o caracteriza como o nono maior produtor mundial. Os Estados de Goiás, São Paulo e Minas Gerais são os principais produtores nacionais; a maior parte da colheita se destina ao mercado in natura, porém a produção de tomates para as indústrias vem crescendo nos últimos anos (Melo \& Vilela, 2005).

Assim como para a maioria das hortaliças, as práticas culturais empregadas na cultura do tomateiro diferem daquelas normalmente utilizadas nas grandes culturas perenes. Destaca-se, nesse caso, o intenso distúrbio no solo devido ao uso de arado, grade, enxada rotativa e sulcadores, em cultivos sucessivos,

1 Recebido para publicação em 12.2.2009 e na forma revisada em 12.3.2010.

2 Professor, Universidade Federal de Viçosa, Campus Rio Paranaíba - UFV-CRP, Rod BR 354, km 310, Caixa Postal 22, $38810-000$ Rio Paranaíba-MG, <claudiopagotto@ufv.br>; ${ }^{3}$ Pesquisador, Instituto Capixaba de Pesquisa, Assistência Técnica e Extensão Rural - INCAPER, Rod. Br 101, Km 151, Caixa Postal 62, 29915-140 Linhares-ES, <lalserrano@incaper.es.gov.br>; ${ }^{4}$ Professor, Dep. de Fitotecnia, Universidade Federal de Viçosa - DFT/UFV, 36570-000 Viçosa-MG, <aasilva@ufv.br>; ${ }^{5}$ Graduando em Agronomia, UFV-CRP, <otavio.guimaraes@ufv.br>. 
na mesma área, com diferentes espécies hortícolas. Além disso, o uso de níveis elevados de adubações químicas e orgânicas, associado a irrigações diárias, contribui para o aparecimento e desenvolvimento de populações de plantas daninhas de dificil controle, que exercem forte interferência negativa na cultura (Pereira, 2000). Outro fator a ser considerado é o espaçamento utilizado no cultivo do tomateiro (superior a $1,0 \mathrm{~m}$ entre fileiras), que, associado ao seu desenvolvimento lento nas primeiras semanas após o transplantio (ou semeadura), favorece o desenvolvimento de espécies infestantes que podem comprometer o desenvolvimento e a produtividade da cultura.

De modo geral, tem-se observado que a presença de plantas daninhas na área de cultivo resulta em reduções significativas na produtividade do tomateiro, sendo, portanto, imprescindivel o manejo dessas plantas para que se possa obter elevada produtividade. Nesse sentido, discute-se neste texto o manejo integrado de plantas daninhas, as principais causas e consequências da competição que elas exercem com o tomateiro, além de aspectos detalhados sobre o período crítico de competição das plantas daninhas durante o ciclo da cultura. São apresentados ainda alguns métodos de controle de plantas daninhas comumente empregados nessa cultura.

\section{Interferência das plantas daninhas na cultura}

Em diagnóstico realizado para identificar os desafios e perspectivas para a cadeia brasileira do tomate industrial, Melo \& Vilela (2005) constataram que a otimização do manejo cultural, que abrange o controle de plantas daninhas, é um dos fatores que exercem influência marcante sobre os custos de produção e a qualidade final do produto.

Devido à arquitetura de copa e espaçamento de cultivo, o tomateiro favorece a ocorrência de plantas daninhas durante o seu ciclo de vida (Nascente et al., 2004). As plantas daninhas alteram o crescimento e o desenvolvimento da cultura, com redução do tamanho, peso e número de frutos. Também causam atraso na maturação dos frutos e aumento na quantidade de frutos podres com o aumento do período de convivência entre o tomateiro e as plantas daninhas (Hernandez et al., 2007).

Quanto aos efeitos diretos da interferência das plantas daninhas, foram observadas grandes reduções de produtividade do tomateiro. Em cultivos transplantados, foram observadas reduções de $77 \%$ sob infestação de Chenopodium album, Ambrosia artemisiifolia, Amaranthus spp. e Digitaria sanguinalis (Weaver $\&$ Tan, 1983); 80\% em tomatais infestados por C. album, A. artemisiifolia e Cenchrus longispinus (aproximadamente 180 plantas $\mathrm{m}^{-2}$ ) (Friesen, 1979); 84\%, média de três anos, sob densa infestação por C. album, Amaranthus spp., A. artemisiifolia, Solanum ptycanthum, $D$. sanguinalis e Setaria viridis (Weaver \& Tan, 1987); 76\%, média de dois anos, sob infestação de Amaranthus spp. (Qasem, 1992); 20 a 50\% no primeiro e 11 a $75 \%$ no segundo ano de cultivo, sob infestação de Echinochloa crusgalli (Norris et al., 2001); 76\% sob competição por Bidens pilosa, Brachiaria plantaginea, Nicandra physaloides e Oxalis latifolia (Nascente et al., 2004); e $77 \%$ sob competição de Solanum americanum, com 6 plantas $\mathrm{m}^{-2}$ (Hernandez et al., 2007).

A magnitude da redução na produtividade devido à competição das plantas daninhas depende, entre outros fatores, das espécies infestantes presentes na área. Nascente et al. (2004) verificaram que as perdas na produção de tomate pela interferência de Cyperus esculentum foram inferiores àquelas causadas por Cyperus rotundus. Stall \& Morales-Payan (2003) constararam reduções de produtividade de $39 \%$, em razão dos efeitos de Galinsoga parviflora, e de $93 \%$, devido à competição de B. plantaginea.

Stall \& Morales-Payan (2003) também verificaram quedas na produtividade do tomateiro transplantado de 50 e $81 \%$, devido à infestação de $C$. esculentus (50 plantas $\mathrm{m}^{-2}$ ) e C. rotundus (100 plantas $\left.\mathrm{m}^{-2}\right)$, respectivamente; todavia, perdas de $10 \%$ foram observadas na densidade de 25 plantas $\mathrm{m}^{-2}$, em ambas as espécies de tiririca. Esses autores observaram que a produção de frutos de tamanho médio foi a que sofreu maior redução: a competição de $C$. rotundus reduziu a produção em 43, 52 e $98 \%$, para frutos de classes extragrande, grande e média, respectivamente, enquanto a 
espécie C. esculentus promoveu quedas de produção de 40, 50 e $75 \%$, para frutos daquelas mesmas classes, respectivamente.

Outro fator importante a ser considerado é que, quanto maior a semelhança fisiológica entre duas espécies, mais intensa é a sua competição pelos fatores que se encontram em quantidades limitadas no ecossistema comum, fato observado por Bucklew et al. (2006), com S. Ptycathum, e por Hernandez et al. (2002, 2007), com $S$. americanum. Estes últimos autores verificaram que o índice de competitividade indicou que uma planta de $S$. americanum correspondeu a quase cinco plantas de tomate, o que evidencia a maior agressividade dessa planta daninha em relação à planta cultivada.

Maiores reduções da produção foram observadas para tomateiros oriundos de semeadura direta (99\%), em comparação àquelas verificadas quando se fez o transplantio de mudas (75\%) (Nascente et al., 2004). Em parte, isso pode ser atribuído à maior densidade de plantas daninhas na cultura implantada por semeadura direta (965 plantas $\mathrm{m}^{-2}$ ) que naquela transplantada ( 515 plantas $\mathrm{m}^{-2}$ ). Weaver et al. (1987) também observaram perdas superiores em lavouras de semeadura direta (80-90\%) que naquelas transplantadas (20-25\%).

No entanto, outos fatores, como a maior período crítico de competição das plantas daninhas quando se utiliza o sistema de semeadura direta (Figura 1), como será discutido a seguir, também podem ter contribuído para maior redução na produtividade nesse sistema em comparação àquela observada no sistema de transplantio.

Além de redução de 34\% na produtividade do tomateiro em semeadura direta, devido à competição de plantas daninhas, Ferreira (1981) constatou reduções de $76 \%$ (ensaio 1), $8 \%$ (ensaio 2) e 59\% (ensaio 3) no crescimento das plantas, avaliado pelo acúmulo de matéria fresca aos 52, 90 e 42 dias após a semeadura, respectivamente, para três diferentes ensaios, em diferentes localidades, cuja infestação era de G. parviflora, Lepidium pseudo-didymum, Sonchrus oleraceus, C. rotundus e Oxalis oxyptera (ensaio 1); G. parviflora, D. sanguinalis, B. plantaginea e O. oxyptera (ensaio 2); e G. parviflora,
B. plantaginea, Lepidium pseudo-didymum, B. pilosa, $C$. rotundus e $O$. oxyptera (ensaio 3).

Segundo Pereira (2000), o espaçamento e a densidade de plantio também são fatores importantes no balanço competitivo, pois influenciam a precocidade e a intensidade do sombreamento promovido pela cultura. Plantios mais densos dificultam o desenvolvimento das plantas daninhas, as quais têm que competir mais intensamente com a cultura na utilização dos fatores de produção. Weaver et al. (1987) verificaram que em plantios menos adensados a redução na produtividade causada por Solanum spp. (5 a 10 plantas $\mathrm{m}^{-2}$ ) foi aproximadamente $23 \%$ superior à dos plantios mais densos, para tomate em semeadura direta, evidenciando que a adequação do espaçamento entre fileiras (redução) ou da densidade de plantio na fileira (aumento) pode alterar o balanço da competição em favor da cultura.

Outra forma de as plantas daninhas interferirem diretamente na cultura é por meio da liberação de substâncias aleloquímicas, as quais podem afetar a germinação de sementes, crescimento, o desenvolvimento e a produtividade da cultura, como observado por Castro et al. (1983).

Apesar de provocar redução na produtividade e no tamanho dos frutos, a interferência das plantas daninhas parece não afetar a qualidade do suco de frutos de tomate, avaliada pela cor, consistência e sabor (Friesen, 1979).

Indiretamente, as plantas daninhas ainda podem atuar como hospedeiras de pragas e de patógenos que atacam o tomateiro, podendo até inviabilizar a cultura em determinadas situações (Pereira, 2000; Silva \& Silva, 2007). Arnaud et al. (2007) identificaram as plantas daninhas Amaranthus spinosus, Amaranthus viridis, Ageratum conyzoides e B. pilosa como hospedeiras naturais de begomovírus - gênero de vírus associado à cultura no Brasil. A murcha-bacteriana do tomateiro, causada por Ralstonia solanacearum, infecta espécies de plantas pertencentes a mais de 50 famílias, provocando maiores perdas nas solanáceas. Assim, as plantas invasoras pertencentes a esta família mantêm altas populações da bactéria no solo - característica que dificulta o controle da doença no campo (Baptista et al., 2006). 


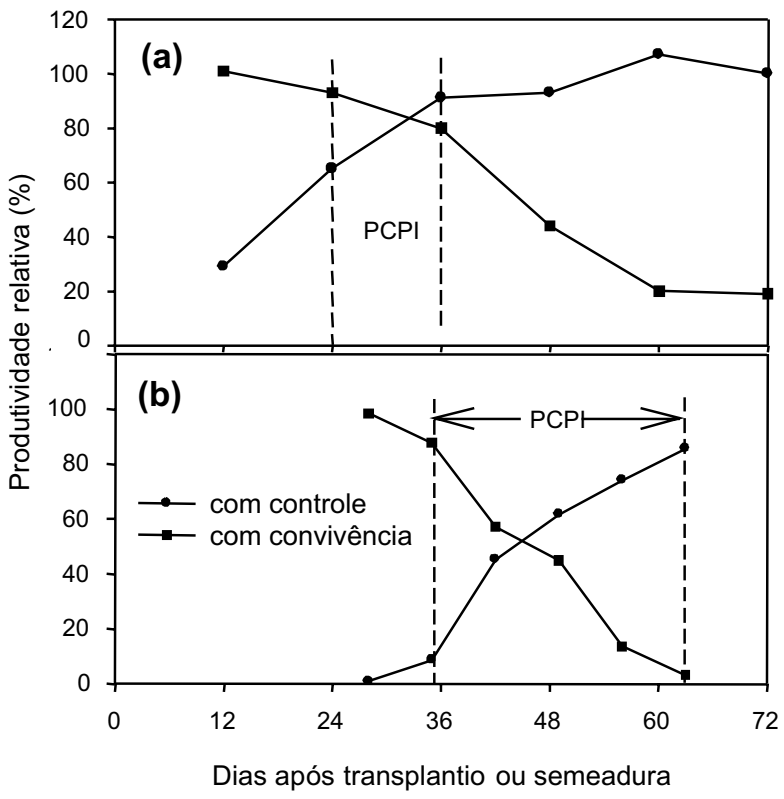

Fonte: Adaptado de Friesen (1979) e Weaver \& Tan (1987). PCPI: período crítico de prevenção da interferência

Figura 1 - Produtividade do tomateiro, expressa em porcentagem em relação àquela obtida nas parcelas com controle durante todo o ciclo da cultura, em parcelas mantidas com controle ou com convivência de plantas daninhas durante diferentes períodos após o transplantio (A) ou semeadura (B).

\section{Periodo critico de competição das plantas daninhas}

O modo correto de se interferir na competição entre as plantas daninhas e a cultura seria neutralizá-la apenas nas épocas adequadas, ou seja, nos períodos em que as plantas daninhas competem efetivamente e prejudicam a produção; mesmo porque, sob certas condições, a cultura e as plantas daninhas podem conviver por pelo menos um período sem que ocorram prejuízos significativos à produção.

Nesse contexto, merecem destaque os conhecimentos do período total de prevenção da interferência (PTPI), do período anterior à interferência (PAI) e do período crítico de prevenção da interferência (PCPI) das plantas daninhas (Silva \& Silva, 2007). O conhecimento desses períodos de convivência de plantas daninhas com a cultura dá ideia clara do momento e da época do ciclo da cultura em que se estabelece a competição, permitindo a otimização das práticas de manejo de plantas daninhas (Ronchi \& Silva, 2006). Todavia, a determinação do período crítico de competição não é simples e requer métodos específicos, porém clássicos, de pesquisas com plantas daninhas.

Na prática, o PCPI representa um intervalo de tempo compreendido entre dois diferentes componentes: a menor extensão de tempo (geralmente medida em dias ou semanas) após a semeadura (ou transplantio) que uma cultura deve ser mantida livre de plantas daninhas para que as plantas que emergirem após esse período não mais causem redução na produtividade - PTPI; e a maior extensão de tempo que as plantas daninhas que emergirem simultaneamente à cultura podem permanecer antes que se desenvolvam suficientemente para competir pelos recursos do ambiente - PAI. Assim, plantas daninhas presentes antes ou após esse intervalo de tempo não alteram o rendimento da cultura, ao passo que aquelas presentes durante esse intervalo devem ser controladas.

Esses conceitos têm grande validade prática, pois se verificou, para grande número de culturas, (i) que sua produção não foi afetada pela presença de plantas daninhas até um determinado estádio após a emergência, desde que a cultura tenha sido mantida no limpo após essa época (Figura 1: período com convivência); e (ii) que, mantendo-se a cultura livre de plantas daninhas até um determinado período após a emergência, as plantas daninhas que emergiram subsequentemente não mais afetarão a produção (Figura 1: período com controle) (Friesen, 1979; Weaver \& Tan, 1983, 1987).

Além de indicar a época (período) em que as plantas daninhas não devem permanecer na lavoura, o limite inferior do PCP indica o momento para que seja realizado o controle de plantas daninhas em pós-emergência, o que não significa dizer que esse é o momento ideal para se realizar a operação de controle. Muitas vezes esse controle deve ser realizado um pouco antes, visando à redução da dose do herbicida e de danos mecânicos ao sistema radicular das culturas, além da redução de custos. Outra informação prática que o PCPI fornece é de que o seu limite superior referese à duração mínima do período em que um 
herbicida aplicado ao solo deveria apresentar atividade residual.

Apesar de variar com as condições edafoclimáticas, os materiais genéticos, a composição e a densidade da comunidade infestante (Ronchi \& Silva, 2006), entre outros, o PCPI foi estabelecido para tomateiros tanto em cultivos a partir do transplantio de mudas (Figura 1A) como em semeadura direta (Figura 1B). No caso da cultura transplantada, enquanto no grupo "com controle" a cultura permaneceu livre da competição de plantas daninhas do transplantio até diferentes períodos do seu ciclo de desenvolvimento, no grupo "com convivência" a cultura permaneceu infestada com as plantas daninhas pelos mesmos diferentes períodos do seu ciclo de vida (Friesen, 1979). Verificou-se que em tomateiros transplantados mantidos livres de plantas daninhas por 36 dias após o transplantio, ou sob competição por 24 dias a partir do transplantio, a produção foi semelhante à daqueles que foram mantidos completamente no limpo durante todo o ciclo da cultura. Diferentemente, quando as plantas daninhas permaneceram por mais de 24 dias após o transplantio, a produtividade foi progressivamente reduzindo. Consequentemente, o período crítico de competição das plantas daninhas no tomateiro situou-se entre o $24^{\circ}$ e o $36^{\circ}$ dia após o transplantio. Raciocínio semelhante pode ser feito no caso de tomateiros em semeadura direta (Weaver \& Tan, 1987).

Além daqueles mencionados no parágrafo anterior, vários PCPIs foram determinados para tomateiros cultivados sob diferentes condições: 28 a 42 dias após o transplantio (DAT) (Sajjapongse et al., 1983) e 28 a 35 DAT (Weaver \& Tan, 1983; Qasem, 1992). Stall \& Morales-Payan (2003) estimaram o PCPI entre 14 e 70 DAT ao considerarem uma perda de $5 \%$ na produção de tomate sob infestação de C. rotundus e $C$. esculentus. Ao admitirem perdas de $10 \%$ na produção, o PCPI se situou entre 18 e 42 DAT, para $C$. rotundus, e entre 28 e 63 DAT, para C. esculentum.

Quanto à interferência das plantas daninhas na cultura do tomateiro para processamento, Nascente et al. (2004) verificaram que o PCPI se situou entre o $33^{\circ}$ e o $76^{\circ}$ DAT. Durante esse período, a taxa média de acúmulo de matéria seca pelas plantas daninhas
(5,2 $\mathrm{g} \mathrm{m}^{-2}$ dia $\left.^{-1}\right)$ implicou uma redução na produção de tomate de $0,57 \mathrm{t} \mathrm{ha}^{-1} \mathrm{dia}^{-1}$. Nesse caso, para cada quilo de matéria seca acumulada pelas plantas daninhas, verificaram-se reduções de 17,86 $\mathrm{kg} \mathrm{ha}^{-1}$ na produção total de frutos e de $11,04 \mathrm{~kg} \mathrm{ha}^{-1}$ na produção de frutos comerciais. Esses mesmos autores também observaram que, aumentando o período do controle inicial das plantas daninhas de 28 para 77 DAT, houve redução no acúmulo de matéria seca dessas plantas e aumento de $67,2 \%$ na produtividade do tomateiro.

Hernandez et al. (2007) estudaram os períodos de interferência de maria-pretinha (S. americanum) sobre o tomateiro industrial e constataram que as diferenças entre a maior e a menor produtividade de frutos maduros, bem como entre o maior e o menor peso médio do frutos, foram de 87 e $35 \%$, respectivamente. Além disso, a maior produtividade e o maior peso médio dos frutos ocorreram quando a convivência entre o tomateiro e a maria-pretinha se deu apenas nos primeiros $15 \mathrm{DAT}$, ao passo que a menor produtividade e o menor peso médio dos frutos decorreram da infestação por todo o ciclo da cultura. Verificaram também que acréscimos de $1,0 \mathrm{~cm}^{2}$ na área foliar, de $1,0 \mathrm{~cm}$ na altura e de $1,0 \mathrm{~g}$ na matéria seca da parte aérea de $S$. americanum reduziram a produtividade do tomateiro em 0,04, 0,82 e $2,84 \mathrm{t} \mathrm{ha}^{-1}$, respectivamente. Considerando-se redução na produtividade do tomateiro de $5 \%$, o PAI foi de 27 DAT; o PTPI, de 46 DAT; e, consequentemente, o PCPI foi de 27 a 46 DAT.

Bucklew et al. (2006) verificaram que a interferência de $S$. ptycanthum prejudicou a produtividade do tomateiro à medida que o periodo de convivência era maior. Recomendaram que no período entre 28 e 50 DAT não deve haver convivência entre as espécies para que as perdas da cultura não ultrapassem 20\%.

Para cultivos em semeadura direta, foi observado o PCPI entre 35 e 63 dias após a semeadura (DAS) (Weaver, 1984; Weaver \& Tan, 1987) e entre 42 e 49 DAS (Weaver $\&$ Tan, 1987). É importante ressaltar que o PCPI, em cultivos formados a partir da semeadura direta, além de iniciar-se mais tardiamente no ciclo da cultura, estende-se por maior número de dias (ou seja, é maior) que quando a lavoura é formada a partir de mudas transplantadas (Figura 1). Isso ocorre devido 
à menor taxa de crescimento inicial da cultura, quando comparada à da planta daninha (Weaver, 1984), e à elevada competição por luz, ou seja, ao sombreamento causado à cultura pelas plantas daninhas, além da competição por água (Weaver \& Tan, 1987). Segundo Weaver \& Tan (1983), os efeitos nocivos da competição sobre a produtividade do tomateiro foram primariamente resultado do sombreamento e não da competição por água.

Observa-se que a extensão do PCPI não é absoluta, pois ela varia com todos os fatores que afetam o sistema de produção (espaçamento de cultivo, espécies e densidades de plantas daninhas, cultivar utilizado, sistema de condução da lavoura - tutoramento ou não, regime hídrico, entre outros). Logo, quando possivel, seria ideal que ele fosse definido para cada situação ou propriedade.

\section{MÉTODOS DE CONTROLE DE PLANTAS DANINHAS}

Em um programa de manejo de plantas daninhas, é necessário ajustar o balanço da interferência entre as plantas, de modo a favorecer o desenvolvimento das hortaliças, e reduzir o crescimento das plantas daninhas e o banco de suas sementes no solo, para que em novos plantios, na mesma área, o nivel de infestação ocorra em menor intensidade. Essas metas podem ser alcançadas por meio do manejo integrado de plantas daninhas (Silva \& Silva, 2007).

O manejo integrado de plantas daninhas visa à utilização conjunta de vários métodos de controle para minimizar a interferência dessas plantas na cultura e manter as suas populações em níveis abaixo daqueles passíveis de causar danos econômicos, além de mitigar os danos ao meio ambiente. A seguir, serão detalhados os principais métodos de controle de plantas daninhas (preventivo, cultural, mecânico e químico), com ênfase na cultura do tomateiro, apesar de a maioria desses métodos aplicar-se, também, ao controle de plantas daninhas em outras hortaliças, em culturas anuais e em perenes.

\section{Controle preventivo}

O controle preventivo de plantas daninhas consiste do uso de práticas que visem prevenir a introdução, o estabelecimento, a reinfestação e a disseminação de determinadas espécies para novas áreas de plantio de tomateiro, sendo o elemento humano a chave do controle preventivo. As principais medidas preventivas são a aquisição de sementes registradas ou certificadas, pois há garantia de um produto livre de sementes de plantas daninhas; a produção de mudas em substratos livres da contaminação com plantas daninhas; a escolha de local para a área de plantio, evitando áreas infestadas com plantas daninhas, principalmente aquelas perenes e/ou que se propagam vegetativamente; e o uso de água de irrigação livre de contaminação com plantas daninhas, pois a maioria das sementes de plantas daninhas flutua sobre a água, enquanto outras conseguem sobreviver submersas por um período prolongado.

$\mathrm{Na}$ tomaticultura transplantada, são necessários cuidados no preparo do substrato para enchimento dos recipientes ou mesmo na aquisição de mudas de terceiros. O uso de substratos comerciais na produção de mudas é um método eficiente para evitar a introdução de espécies daninhas em áreas que não as possuem.

Para a desinfestação do substrato convencional (composto por solo, areia e esterco bovino) ou até mesmo do solo da área que irá receber o plantio, pode-se utilizar a solarização do solo, que é um processo hidrotérmico que esteriliza o solo por meio de calor gerado naturalmente. A solarização atua nas sementes ou propágulos das plantas por meio da ação direta do calor e da umidade, na queima de plântulas germinadas e nas alterações no balanço de gases $\mathrm{O}_{2} / \mathrm{CO}_{2}$, acetaldeído, etileno, entre outros, que afetam a dormência e a germinação das sementes e a sobrevivência das plantas (Elmore, 1991).

A solarização do solo é realizada através da cobertura do solo úmido (com aproximadamente $70 \%$ da capacidade de campo) com filme de polietileno transparente, nas estações mais quentes do ano. Quando realizada antes do plantio, tem demonstrado efetivo controle de patógenos de solo e de plantas invasoras (Ghini, 2001). Segundo Baptista et al. (2006), embora não seja tão eficiente quanto o controle químico, a solarização do solo não apresenta os problemas de toxicidade e danos ao meio 
ambiente, configurando-se em uma alternativa bastante interessante para o sistema orgânico de produção. Baptista et al. (2006) avaliaram a solarização do solo, realizada 65 dias antes do transplantio das mudas de tomateiro, e observaram redução significativa no banco de sementes de plantas invasoras, principalmente o de monocotiledôneas.

Outra prática preventiva é a constante limpeza de máquinas e implementos agrícolas, bem como a utilização de roupas limpas pelas pessoas envolvidas no processo de produção, uma vez que algumas plantas daninhas, como B. pilosa (picão-preto) e Cenchrus echinatus (capim-carrapicho), podem ainda se espalhar por novas áreas, por aderirem com facilidade às roupas dos funcionários de campo.

Existem algumas espécies de plantas daninhas ( $S$. americanum - maria-pretinha, S. sissymbrifolium-joá, $N$. physaloides-joá-decapote, entre outras), pertencentes à mesma família botânica do tomateiro (Solanaceae), cuja introdução na área a ser cultivada com tomate deve ser indiscutivelmente evitada. Essas plantas daninhas, além de hospedeiras de patógenos (nematoides do gênero Melodoigyne) e de produzirem grande quantidade de sementes de fácil disseminação, possuem hábitos de crescimento e fisiologia semelhantes aos do tomateiro, o que dificulta e/ou impossibilita seu controle com herbicidas seletivos para solanáceas (Weaver et al., 1987).

Além disso, o cuidado em se prevenir a introdução de espécies de plantas daninhas na área é particularmente importante para outras espécies de plantas daninhas dicotiledôneas (folhas largas), visto que poucos são os herbicidas disponiveis para uso nessa cultura que são eficientes no controle dessas plantas; e que quase todos são exclusivamente graminicidas. Ademais, o manejo inadequado das áreas cultivadas com hortaliças pode promover a disseminação ou até mesmo a introdução de espécies de plantas daninhas perenes de difícil controle, como a Artemisia verlotorum (losnabrava) e a tiririca.

\section{Controle cultural}

Consiste em usar as próprias características ecológicas das culturas e plantas daninhas visando beneficiar o estabelecimento e desenvolvimento da cultura e dificultar o crescimento pleno das plantas daninhas, ou seja, utilizar-se das melhores práticas culturais para que a cultura sobrepuje o desenvolvimento das plantas daninhas. Essas práticas podem ser: plantio de variedades adaptadas às condições de clima e solo; uso de sementes de boa qualidade e devidamente tratadas; mudas formadas em recipientes adequados, com sistema radicular bem desenvolvido; plantio em época certa, utilizando espaçamentos e arranjos de plantas adequados para as diferentes variedades; adequado preparo do solo; e adubações de plantio e formação balanceadas. Com o uso dessas práticas culturais, consegue-se direta ou indiretamente eliminar ou reduzir a infestação por plantas daninhas (Silva \& Silva, 2007).

Em algumas propriedades, a prática da "amontoa", cuidadosamente realizada três semanas após o transplantio, constitui-se numa operação indireta de controle de plantas daninhas, uma vez que coincide com o período crítico de competição.

A rotação de culturas também constitui importante método cultural de controle de plantas daninhas. As culturas em rotação com a cultura do tomateiro, numa mesma área, devem pertencer a famílias botânicas diferentes, para que se reduza o banco de sementes do solo e facilite o manejo das plantas daninhas. Com a rotação de culturas, a dinâmica das plantas daninhas se altera, e com ela se alteram também os métodos de controle e, sobretudo, os herbicidas com diferentes espectros de ação. Para que se obtenha sucesso com o sistema de rotação de culturas, é necessário conhecer detalhadamente o histórico da área cultivada, qual a espécie de planta daninha dominante e principalmente sobre os herbicidas utilizados na cultura anterior, suas doses e efeitos residuais no solo, a fim de que a lavoura em sucessão não seja intoxicada por herbicidas ainda presentes no solo.

Um exemplo de sucesso de rotação de culturas tem sido o cultivo de milho ou de feijão em áreas anteriormente cultivadas com tomateiro e que apresentam alto grau de infestação por $C$. rotundus. O cultivo nessas áreas - do milho seguido de feijão em sistema de plantio direto, por dois anos seguidos - tem 
reduzido em mais de $90 \%$ a infestação de tiririca (Cyperus sp.), tornando viável o cultivo de hortaliças após essa rotação (Jakelaitis et al., 2003a,b). Pereira et al. (1995) também relatam que o milho é uma boa opção de cultura para compor um sistema de rotação com do tomateiro. Em algumas regiões do Brasil, Brachiaria spp. também tem sido usada com sucesso, compondo sistemas de rotação.

A composição e a densidade populacional de uma comunidade infestante são influenciadas pelo sistema de produção de cobertura morta (Correia et al., 2006). A cobertura morta tem efeitos físicos (interferência na germinação e na taxa de sobrevivência das plântulas), químicos (efeito alelopático) e biológicos (instalação de uma densa e diversificada microbiocenose na camada superficial do solo) sobre as plantas daninhas (Trezzi \& Vidal, 2004; Gomes Jr. \& Christoffoleti, 2008; Monquero et al., 2009).

Assim, das inúmeras vantagens conhecidas do sistema de plantio direto - prática que mantém o solo coberto por resíduos vegetais destaca-se a melhoria no controle de plantas daninhas. Marouelli et al. (2006) verificaram que o sistema de plantio direto proporcionou acréscimo na produtividade do tomateiro para processamento quando comparado ao sistema convencional, sendo esta maximizada na quantidade de $6 \mathrm{t} \mathrm{ha}^{-1}$ de matéria seca de sorgo forrageiro. Trezzi \& Vidal (2004) constataram que a presença de resíduos da parte aérea de sorgo $\left(4 \mathrm{tha}^{-1}\right)$ foi suficiente para reduzir 91 , 96 e 59\% da população de Sida rhombifolia, B. plantaginea e B. pilosa, respectivamente.

No plantio direto para a cultura do tomateiro, o manejo da cultura antecessora ou das plantas de cobertura do solo (fornecedora da palhada) pode ser feito usando-se rolo-faca, roçado ou por meio da dessecação com herbicidas. Os sulcos para a adubação e o plantio devem ser abertos em curvas de nivel e preparados aproximadamente três semanas antes do plantio, para que haja melhor incorporação dos adubos. Procede-se, então, à marcação do espaçamento entre plantas, à abertura das covas ao longo das linhas de plantio e, por fim, ao plantio das mudas. A prática da amontoa, normalmente utilizada na cultura, não é realizada no sistema de plantio direto; assim, evita-se o revolvimento do solo e o possivel aumento da infestação de plantas daninhas (Wamser \& Mueller, 2008).

Ao estudarem a produção de palha e supressão de plantas daninhas por plantas de cobertura, no plantio direto do tomateiro rasteiro, Silva et al. (2009) verificaram que a produtividade não foi influenciada pelas culturas de cobertura Crotalaria juncea, Stizolobium aterrimum e Pennisetum glaucum. Entretanto, C. juncea e o P. glaucum isoladas e consorciadas entre si ou com $S$. aterrimum reduziram a emergência e o acúmulo de matéria seca de plantas daninhas. Monquero et al. (2009) também observaram a eficiência de $C$. juncea, $P$. glaucum e Mucuna aterrima na redução de germinação de Ipomoea grandifolia, Brachiaria decumbens e Panicum maximum. Segundo Suzuki \& Alves (2006), o rápido estabelecimento e desenvolvimento de $C$. juncea e Pennisetum spp. favorecem a diminuição na incidência de plantas daninhas.

É válido destacar que no sistema de plantio direto ocorrem algumas espécies de plantas daninhas comumente não observadas no sistema convencional, pois o não revolvimento do solo favorece o desenvolvimento e o aumento da população de espécies de plantas daninhas perenes (Jakelaitis et al., 2003b; Silva et al., 2005; Gomes Jr. \& Christoffoleti, 2008).

\section{Controle mecânico}

O controle mecânico consiste no uso de práticas de eliminação de plantas daninhas por meio de efeito físico-mecânico, seja por tração humana, animal ou tratorizada. Nesse método, o preparo periódico do solo promove o controle de plantas daninhas através do efeito mecânico de quebra, do arranque e da exposição das estruturas das plantas à secagem pelo sol, fato que promove a redução do banco de sementes do solo (Silva et al., 2005). Apesar de eficiente (solo com baixa umidade), esse método geralmente é utilizado de forma complementar a outros, uma vez que apresenta baixo rendimento, demanda muita mão de obra e é de alto custo. Ademais, o revolvimento contínuo do solo pode promover o aumento da infestação de algumas espécies de plantas que 
se propagam vegetativamente (Jakelaitis et al., 2003b; Silva et al., 2005).

O tomateiro possui sistema radicular muito ramificado, com grande quantidade de raízes situadas próximo à superfície do solo. Dessa forma, as capinas podem prejudicar o tomateiro diretamente, causando danos mecânicos ao caule, ou indiretamente, criando portas de entrada para microrganismos fitopatogênicos ou mesmo estimulando a ocorrência da podridão estilar (deficiência de $\mathrm{Ca}$ ), uma vez que a absorção desse cátion pelas raízes cortadas do tomateiro pode ser prejudicada.

O controle mecânico de plantas daninhas ainda jovens, na entrelinha de plantio, pode ser feito com cultivadores acoplados a microtratores, visto que estes se adequam ao espaçamento da cultura, ou utilizando-se de carpideiras de tração animal. Esse equipamento é mais eficiente no controle de espécies daninhas anuais e em condições de calor e solo seco, porém apresenta como desvantagem principal a incapacidade de controlar plantas daninhas na linha de plantio.

Nos EUA é comum a prática de cobertura do solo por plástico na produção de tomate para mesa. A cobertura de plástico protege a planta contra pragas do solo, controla a incidência de plantas daninhas, conserva a umidade próxima à superfície do solo e aumenta a concentração de raízes na parte mais aquecida e mais fértil do perfil do solo (Tsekleev et al., 1993). Sampaio et al. (1999) não observaram influência da cobertura plástica sobre o rendimento do tomateiro; entretanto, Talavera \& Padilla (2000) observaram que a utilização de cobertura com plásticos negro e gris proporcionaram maior produção de frutos quando comparada a coberturas orgânicas (serragem, bagaço-decana e casca de arroz) e à testemunha (aplicação de trifluralina pré-plantio e capina manual pós-plantio).

\section{Controle químico}

Nas situações em que o período crítico de prevenção da interferência de plantas daninhas é muito longo, a principal medida de controle para minimizar as perdas de produtividade é o uso de herbicidas aplicados em área total, uma vez que o controle mecânico exigiria elevada frequência de operações, o que aumentaria o custo de produção, além de aumentar os riscos da infecção por doenças (Hernandez et al., 2007). Como a utilização dos métodos mecânicos de controle de plantas daninhas, seja por meio de capinas manuais ou pelo uso de cultivadores, pode prejudicar as raízes superficiais e o caule do tomateiro, e considerando-se os custos elevados da mão de obra para as capinas e a necessidade de melhor controlar as plantas daninhas na linha de plantio, os herbicidas são uma importante ferramenta nas lavouras de tomate mais tecnificadas.

As vantagens do emprego do herbicida são várias: controle em pré-emergência, eliminando as plantas daninhas precocemente; atinge alvos que a enxada ou o cultivador não alcançariam, como as plantas daninhas na linha de plantio; reduz ou elimina os riscos de danos às raízes e às plantas novas; não modifica a estrutura do solo e, portanto, reduz o risco de erosão; controla mais eficientemente as plantas daninhas perenes; reduz a necessidade de mão de obra; aumenta a rapidez e a eficiência da operação de controle por unidade de área, reduzindo o custo por área tratada; controla as plantas daninhas por um período mais longo, quando a utilização de cultivador é impossivel, tendo em vista o crescimento da cultura; e pode ser usado em períodos chuvosos, quando o controle mecânico não é eficiente e quando a mão de obra é requerida para outras atividades. Contudo, apresenta a desvantagem de necessitar de mão de obra especializada, pois, se efetuado inadequadamente, pode intoxicar a lavoura, o meio ambiente e, principalmente, o próprio aplicador; apesar de os herbicidas serem muito eficientes no controle de plantas daninhas, podem favorecer o desenvolvimento de biótipos resistentes, fato que agravaria ainda mais o problema dentro de uma área cultivada (Gomes Jr. \& Christoffoleti, 2008).

Para utilização de herbicidas, alguns aspectos devem ser considerados: a identificação das principais espécies de plantas daninhas presentes na área, seu estádio de desenvolvimento e grau de infestação; o estádio de desenvolvimento das plantas de tomateiro; o custo da aplicação; as análises física, química e do teor de matéria orgânica 
do solo, para a adequação das doses; as condições climáticas previstas para o momento da aplicação, principalmente de ventos; a adequação de equipamentos (pontas e barras de pulverização) e das condições de trabalho (volume de calda, pressão, altura de barra, ou seja, a calibração do pulverizador), para se obter boa distribuição da calda e boa cobertura do alvo, potencializando a eficiência do herbicida e mitigando os efeitos prejudiciais da deriva; e a seletividade do herbicida à cultura e seu efeito residual para as culturas subsequentes, entre outros.

De acordo com a ANVISA (2009), os herbicidas atualmente registrados para a cultura do tomateiro são à base de clethodin, flazasulfuron, fluazifop-p-butil, metam-sódico, metribuzim, napropamida, quizalofop-p-ethyl e trifluralin. Desses, os mais utilizados na cultura são o metribuzin, o clethodin, o fluazifop-p-butil, o trifluralin e o flazasulfuron.

Devido à baixa tolerância que o tomateiro apresenta a herbicidas pós-emergentes, o controle de plantas daninhas dicotiledôneas é mais complicado quando comparado ao controle de gramíneas (Ormeño et al., 2003). À exceção do metribuzim e do flazasulfurom, os demais herbicidas registrados para a cultura são utilizados exclusivamente no controle de gramineas. Portanto, é possível inferir maior facilidade no controle das plantas daninhas gramineas pelo método químico, enquanto para as dicotiledôneas esse controle nem sempre é possivel, sendo muitas vezes necessária a integração do método químico ao mecânico para se manter a cultura livre da concorrência das plantas daninhas.

Na cultura do tomateiro, o metribuzim é o herbicida de maior utilização no Brasil, sendo aplicado tanto em pré-emergência, quando em semeadura direta, como em pós-transplantio de mudas. Neste caso, é aplicado entre as duas primeiras semanas após o transplantio (Bachega et al., 2005) ou, mais precisamente, em até 10 dias após o transplante (Silva \& Silva, 2007).

O metribuzim controla diversas espécies de dicotiledôneas e algumas gramíneas, porém não apresenta nenhum controle sobre E. heterophylla e em espécies de plantas daninhas solanáceas ( $S$. americanum, N. physaloides) (Silva, 1989). Atua como inibidor do fotossistema II e é muito dependente das condições edafoclimáticas para seu bom funcionamento (Silva \& Silva, 2007). É muito adsorvido em solos com alto teor de matéria orgânica e/ou argila. Quando aplicado na superficie de solo seco e persistir nessa condição por sete dias, é desativado por fotodegradação. É, também, facilmente lixiviado no solo, não sendo recomendado seu uso em solo arenoso e/ou com baixo teor de matéria orgânica (Silva, 1989).

Godoy et al. (2007) constataram que o metribuzim promoveu controle eficaz em pós e em pré-emergência das plantas daninhas mesmo sem ocorrência de chuvas após a aplicação. Entretanto, a duração do período de controle após a aplicação variou de acordo com o número de dias sem ocorrência de chuvas, sendo de sete dias após a aplicação para o controle de I. grandifolia e 14 dias para S. rhombifolia.

Apesar de proporcionar excelente controle de plantas daninhas, o metribuzim pode ser fitotóxico sob determinadas condições ambientais. Por exemplo, foi observado que dias nublados antes da aplicação podem fazer com que as plantas se tornem menos tolerantes a esse herbicida, assim como a maior disponibilidade de água às plantas. Neste caso, acreditase que a maior retenção de água no solo provoca aumento no período de permanência do produto junto às raízes do tomateiro, potencializando sua absorção pela planta (Bachega et al., 2005). Também foram observadas algumas diferenças quanto à tolerância de diferentes cultivares ao metribuzim, em que cultivares mais precoces parecem ser mais sensiveis que os tardios.

Tanto o clethodin como o fluazifop-p-butil são inibidores da ACCase (Silva \& Silva, 2007) e são recomendados para uso em pósemergência, devendo ser aplicados no início do desenvolvimento das plantas daninhas (quatro folhas ou até quatro perfilhos, quando provenientes de sementes). Para se obter maior eficiência na aplicação desses herbicidas, eles devem ser aplicados quando as plantas daninhas apresentarem bom vigor vegetativo. Recomenda-se, também, evitar 
períodos de estiagem, horas de muito calor e umidade relativa do ar inferior a $60 \%$.

O trifluralin, inibidor do arranjo de microtúbulos (Silva \& Silva, 2007), é um herbicida que apresenta excelente ação sobre as gramineas anuais e perenes oriundas de sementes. Por ser um produto volátil, sensivel à luz e de solubilidade em água extremamente baixa, necessita ser incorporado mecanicamente ao solo logo após a sua aplicação. A dose recomendada varia de acordo com as características fisico-químicas do solo. Esse herbicida somente deve ser recomendado para a cultura do tomate quando em mistura com metribuzin, devendo ser aplicado em pré-plantio incorporado (PPI). Quando a área de cultivo estiver infestada apenas por gramíneas, sua aplicação é considerada mais segura ambientalmente e mais eficiente (Silva \& Silva, 2007).

O flazasulfuron, inibidor da enzima acetolactato sintase, pertence ao grupo das sulfonilureias, apresenta seletividade ao tomateiro e controle eficiente de plantas daninhas anuais e bianuais quando aplicado em pré-emergência (Kogan \& Figueroa, 2002). Casera (1997) avaliou a atividade do flazasulfuron aplicado em pré e pós-transplantio em tomate industrial e verificou que o melhor resultado de controle das plantas daninhas (gramineas e dicotiledôneas anuais) ocorreu quando ele foi aplicado em prétransplantio incorporado nas doses de 75 e $100 \mathrm{~g}$ i.a. ha $\mathrm{h}^{-1}$. A aplicação desse herbicida em pós-transplantio não proporcionou resultados satisfatórios de controle.

O quizalofop-p-ethyl pertence ao grupo químico do ácido ariloxifenoxipropiônico, sendo recomendado para o controle de gramíneas em pós-emergência. O napropamida pertence ao grupo químico alcanamida e é recomendado para o controle de gramineas em pré-emergência, com aplicação em pré-plantio incorporado ao solo. O metam-sódico pertence ao grupo químico isotiocianato de metila, sendo recomendado para o controle pós-emergente de plantas daninhas gramineas e algumas dicotiledôneas (ANVISA, 2009).

Duran (1994) avaliou o efeito de diferentes herbicidas aplicados na cultura do tomateiro oriundo de semeadura direta e concluiu que, em pré-semeadura, trifluralin $\left(1,25\right.$ e $1,68 \mathrm{~kg}$ i.a. ha $\left.{ }^{-1}\right)$ e napropamida $\left(2,25 \mathrm{~kg}\right.$ i.a. $\left.\mathrm{ha}^{-1}\right)$ foram os herbicidas que proporcionaram o melhor controle de plantas daninhas e os maiores rendimentos de produção. Na fase de pré-emergência da cultura, os melhores resultados foram obtidos com napropamida $\left(3,0 \mathrm{~kg}\right.$ i.a. ha $\left.{ }^{-1}\right)$. Os herbicidas metobromuron, aplicado em pré-emergência, e nicosulfuron, aplicado em pós-emergência, causaram fitotoxidez, como clorose, necrose, aborto floral e diminuição no crescimento das plantas.

Apablaza (1994) estudou o manejo das plantas daninhas no cultivo do tomateiro industrial oriundo de transplantio e concluiu que os melhores controles de plantas daninhas resultaram da aplicação em pré-transplantio (7 dias) de pendimethalin (1,32 kg i.a. ha $\left.{ }^{-1}\right)+$ metribuzin $\left(0,37 \mathrm{~kg}\right.$ i.a. ha $\left.{ }^{-1}\right)$; e trifluralina $\left(0,96 \mathrm{~kg}\right.$ i.a. ha $\left.{ }^{-1}\right)+$ metribuzin $(0,37 \mathrm{~kg}$ i.a. ha-1) A aplicação adicional de metribuzin (0,37 kg i.a. ha $\left.{ }^{-1}\right)$ pós-transplante (30 dias), nesses mesmos tratamentos, aumentou ainda mais a eficiência do controle de plantas daninhas.

Gilreath (1981), na Flórida, testou vários herbicidas na cultura do tomateiro e concluiu que os melhores resultados de controle das plantas daninhas e a maior produtividade total de frutos foram obtidos pelo napropamida em combinação com metribuzim. Nenhum herbicida avaliado controlou a tiririca (C. rotundus), e apenas o herbicida acifluorfen provocou intoxicação no tomateiro. Ainda na Flórida, Gilreath \& Santos (2004) conseguiram controle satisfatório de $C$. rotundus na cultura do tomateiro, utilizando-se de misturas de herbicidas com fumegantes (napropamida e pebulato).

Outros herbicidas não registrados para a cultura no Brasil também já foram testados em outros países. No Canadá, Robinson et al. (2006) avaliaram a aplicação conjunta de herbicidas e fungicidas na cultura do tomateiro e concluíram que os herbicidas rimsulfurom e thifensulfurom (inibidores de ALS) podem ser aplicados isoladamente ou misturados com baixas doses de metribuzin e clorotalonil para o controle simultâneo de plantas daninhas e doenças na cultura.

Na Venezuela, Finol et al. (1999) observaram que o halosulfuron-metílico, aplicado 
aos 7 DAT do tomateiro, foi efetivo no controle de plantas daninhas por um periodo de 45 dias nas doses de 0,100 e 0,125 kg i.a. ha ${ }^{-1}$, sendo também considerado seletivo para a cultura. Ao se misturar halosulfuron-metílico+ acetocloro $(0,075+0,014),(0,075+0,018)$ ou $(0,100,0+0,014)$, em $\mathrm{kg} \mathrm{ha}^{-1}$, verificou-se controle ainda mais efetivo das plantas daninhas, porém essas misturas causaram redução na matéria seca das plantas de tomateiro.

No Chile, Ormeño et al. (2003) utilizaram o herbicida halosulfuron-metílico (75 $\left.\mathrm{g} \mathrm{ha}^{-1}\right)$ em aplicação em pós-emergência da cultura (aos 30 DAT) para o controle da tiririca e observaram que o tomateiro apresentou alto grau de tolerância a esse herbicida (apenas toxicidade inicial nas folhas até 15 dias após a aplicação), porém sem afetar o rendimento, número e tamanho dos frutos.

O glifosato, herbicida aplicado em pósemergência e não seletivo, é largamente utilizado no Brasil em quase todas as culturas; contudo, a deriva desse produto vem sendo citada como um dos fatores que interferem negativamente na cultura do tomateiro. Assim, Figueredo et al. (2007) estudaram a influência de doses reduzidas do glifosato sobre o tomateiro e concluíram que a aplicação de doses a partir de $378 \mathrm{~g} \mathrm{ha}^{-1}$ aumenta a toxicidade e reduz a altura de planta e o número de cachos, flores e frutos de tomate, independentemente do estádio de desenvolvimento da cultura.

\section{CONSIDERAÇÕES FINAIS}

Em resumo, o controle químico deve ser feito juntamente com outras práticas de controle, sendo a de maior importância o controle cultural, uma vez que este possibilita as melhores condições de desenvolvimento e permanência da cultura, cabendo ao controle químico apenas complementar quando necessário. Portanto, um programa eficiente de manejo de plantas daninhas na cultura do tomateiro deve integrar todos os métodos aqui abordados. Estes devem ser escolhidos, entre outros fatores, em função das condições individuais de cada lavoura, dos recursos disponíveis, das espécies infestantes presentes na área, do tipo de solo, da topografia do terreno, dos equipamentos disponíveis na propriedade, das condições ambientais e do nivel cultural do produtor.

Um programa adequado de manejo de plantas daninhas deve permitir a máxima produção no menor espaço de tempo, a máxima sustentabilidade de produção e o mínimo risco econômico e ambiental. Para isso, é de fundamental importância conhecer a capacidade competitiva das espécies infestantes (biologia e danos, principalmente), a densidade e a distribuição destas espécies e, se possível, estimar o período total de prevenção da interferência (PTPI), o período anterior à interferência (PAI) e o período crítico de prevenção da interferência (PCPI) das plantas daninhas, para cada situação.

\section{LITERATURA CITADA}

AGÊNCIA NACIONAL DE VIGILÂNCIA SANITÁRIA ANVISA - SIA: Sistema de Informações sobre Agrotóxicos. Disponível em: < www4 anvisa.gov.br/AGROSIA > Acesso em: 17 mar. 2009.

APABLAZA, E. P. U. Manejo de las malezas en el cultivo del tomate industrial (Lycopersicum esculentum Mill.) con herbicidas de pre y postransplante [pendimetalin; metribuzina; napropamida; trifluralina]. 1994. 83 f. Tesis (Ing. Agr.) - Universidad de Chile, Esc. de Agronomia, Santiago, 1994

ARNAUD, L. S. E. P. et al. Predominância de begomovírus em tomateiros na região produtora da Ibiapaba, Ceará, e sua detecção natural em plantas daninhas. Fitopatol. Bras., v. 32, n. 3, p. 241-246, 2007.

BACHEGA, T. F.; HERNANDEZ, D. D.; ALVES, L. C. A. Tomate: tolerância sob medida. Cult. Hort. Frutas, n. 31, p. $10-14,2005$

BAPTISTA, M. J. et al. Efeito da solarização e biofumigação na incidência da murcha bacteriana em tomateiro no campo. Hortic. Bras., v. 24, n. 2, p. 161-165, 2006.

BUCKLEW, J. K. et al. Eastern black nightshade (Solanum ptycanthum) reproduction and interference in transplanted plasticulture tomato. Weed Sci., v. 54, p. 490-495, 2006.

CASERA U. W. A. Actividad de flazasulfuron aplicado en pre y post-transplante en tomate industrial (Lycopersicum esculentum Mill.). 1997. 65 f. Tesis (Ing. Agr.) - Universidad de Chile, Esc. de Agronomia, Santiago, 1997. 
CASTRO, P. R. C. et al. Efeitos alelopáticos de alguns extratos vegetais na germinação do tomateiro (Lycopersicum esculentum Mill. Cv. Santa Cruz). Planta Daninha, v. 6, n. 2, p. $79-85,1983$

CORREIA, N. M.; DURIGAN, J. C.; KLINK, U. P. Influência do tipo e da quantidade de resíduos vegetais na emergência de plantas daninhas. Planta Daninha, v. 24, n. 2 , p. 245-253, 2006.

DURAN, M. P. Evaluación del efecto de diferentes herbicidas en la siembra directa de tomate (Lycopersicon esculentum, Mill) híbrido variedad Nema 1401. 1994. 74 f. Tesis (Ing. Agr.) - Universidad de Chile, Esc. de Agronomia, Santiago, 1994

ELMORE, C. L. Weed control by solarization. In. KATAN, J.; DEVAY, J. E. (Eds.). Soil solarization. Boca Raton: CRC Press, 1991. p. 61-72

FERREIRA, L. R. Controle químico de plantas daninhas na cultura do tomate (Lycopersicon esculentum, Mill) semeado diretamente no local definitivo. 1981. $55 \mathrm{f}$. Dissertação (Mestrado em Fitotecnia) - Universidade Federal de Viçosa, Viçosa, MG, 1981

FIGUEREDO, S. S. et al. Influência de doses reduzidas do glyphosate no tomateiro (Lycopersicon esculentum). Planta Daninha, v. 25, n. 3, p. 849-857, 2007.

FINOL, E. L. et al. Evaluación de la efícacia del herbicida halosulfuron metil, aplicado solo y en mezcla con acetocloro en tomate Lycopersicon esculentum Mill. Revista de la Facultad de Agronomía (LUZ), v. 16, n. 3, p. 266-275, 1999

FRIESEN, G. H. Weed interference in transplanted tomatoes (Lycopersicon esculentum). Weed Sci., v. 27, p. 11-13, 1979.

GILREATH, J. P. Evaluation of herbicides for weed control in tomato. Proc. Fla. State Hortic. Soc., v. 94, p. 129-131, 1981

GILREATH, J. P.; SANTOS, B. M. Manejo de Cyperus rotundus (coquillo) con alternativas al bromuro de metilo, em tomate de mesa. Manejo Integrado Plagas Agroecol., v. 71, p. 54-58. 2004.

GHINI, R. Alternativas para substituir o brometo de metila na agricultura. Summa Phytopathol., v. 27, p. 162, 2001

GODOY, M. C. et al. Efeito da cobertura morta de milheto (Pennisetum americanum) sobre a eficácia do herbicida metribuzin no controle de Ipomoea grandifolia e Sida rhombifolia. Planta Daninha, v. 25, n. 1, p. 79-86, 2007.

GOMES JR., F. G.; CHRISTOFFOLETI, P. J. Biologia e manejo de plantas daninhas em áreas de plantio direto. Planta Daninha, v. 26, n. 4, p. 789-798, 2008.
HERNANDEZ, D. D.; ALVES, P. L. C. A.; SALGADO, T. P. Efeito da densidade e proporção de plantas de tomate industrial e de maria-pretinha em competição. Planta Daninha, v. 20, n. 2, p. 229-236, 2002

HERNANDEZ, D. D. et al. Períodos de interferência de maria-pretinha sobre tomateiro industrial. Hortic. Bras., v. 25, n. 2, p. 199-204, 2007.

IBGE - Instituto Brasileiro de Geografia e Estatística Produção Agrícola Municipal. Disponível em: <http// www. sidra.ibge.gov.br>. Acesso em: 28 julho de 2009.

JAKELAITIS, A. et al. Efeitos de sistemas de manejo sobre a população de tiririca. Planta Daninha, v. 21, n. 1, p. 89-95, 2003a.

JAKELAITIS, A. et al. Dinâmica populacional de plantas daninhas sob diferentes sistemas de manejo nas culturas de milho e feijão. Planta Daninha, v. 21, n. 1, p. 71-79, 2003 b.

KOGAN, M.; FIGUEROA, R. Persistencia de la actividad en el suelo de flazasulfuron aplicado después del transplante del tomate. Ci. Invest. Agr., v. 29, n. 3, p. 137-143. 2002.

MAROUELLI, W. A.; SILVA, H. R.; MADEIRA, N. R. Uso de água e produção de tomateiro para processamento em sistema de plantio direto com palhada. Pesq. Agropec. Bras., v. 41, n. 9, p. 1399-1404, 2006.

MELO, P. C. T.; VILELA, N. J. Desafios e perspectivas para a cadeia brasileira do tomate para processamento industrial. Hortic. Bras., v. 23, n. 1, p. 154-157, 2005.

MONQUERO, P. A. et al. Efeitos de adubos verdes na supressão de espécies de plantas daninhas. Planta Daninha, v. 27, n. 1, p. 85-89, 2009.

NASCENTE, A. S.; PEREIRA, W.; MEDEIROS, M. A. Interferência das plantas daninhas na cultura do tomate para processamento. Hortic. Bras., v. 22, n. 3, p. 602-606, 2004.

NORRIS, R. F. et al. Spatial arrangement, density, and competition between barnyardgrass and tomato: I. Crop growth and yield. Weed Sci., v. 49, n. 1, p. 61-68, 2001.

ORMEÑO N. J.; FUENTES V. F.; SOFFIA C. V. Tolerancia del tomate (Lycopersicon esculentum Mill.) a aplicaciones post transplante del herbicida halosulfuron-metil. Agric. Técnica, v. 63, n. 2, p. 125-134, 2003.

PEREIRA, W. Manejo de plantas daninhas. In: SILVA, J. B. C.; GIORDANO, L. B. Tomate para processamento industrial. Brasília: Embrapa Comunicação para Transferência de Tecnologia/Embrapa Hortaliças, 2000 p. 72-87. 
PEREIRA, W. et al. Avaliação da dinâmica de plantas daninhas sob oito diferentes sistemas de sucessão de culturas no cultivo do tomate para processamento industrial. Hortic. Bras., v. 13, n. 1, p. 104, 1995.

QASEM, J. R. Pigweed (Amaranthus spp.) interference in transplanted tomato (Lycopersicon esculentum). J. Hortic. Sci., v. 67, n. 3, p. 421-427, 1992.

ROBINSON, D. F. et al. Weed control in processing tomato ((Lycopersicon esculentum) with rimsulfuron and thifensulfuron applied alone or with chlorothalonil or copper pesticides. HortSci., v. 41, n. 5, p. 1295-1297, 2006

RONCHI, C. P.; SILVA, A. A. Effects of weed species competition on the growth of young coffee plants. Planta Daninha, v. 24, n. 3, p. 415-423, 2006.

SAJJAPONGSE, A.; SELLECK, G. W.; ROAN, Y. C. Weed control for transplanted tomato. Acta Hortic., v. 136, n. 1, p. $65-68,1983$.

SAMPAIO, R. A.; FONTES, P. C. R.; SEDIYAMA, C. S. Resposta do tomateiro à fertirrigação potássica e cobertura plástica do solo. Pesq. Agropec. Bras., v. 34, n. 1, p. 21-30, 1999.

SILVA, A. A. Bioatividade do alachor e do metribuzin sob diferentes manejos de água e efeitos do metribuzin, sob estas condições em soja. 1989. 138 f. Tese (Doutorado) Escola Superior de Agricultura "Luiz de Queiroz", Piracicaba, 1989.

SILVA, A. A.; SILVA, J. F. Tópicos em manejo de plantas daninhas. Viçosa, MG: Universidade Federal de Viçosa, 2007. 367 p.

SILVA, A. A. et al. Aspectos fitossociológicos da comunidade de plantas daninhas na cultura do feijão sob diferentes sistemas de preparo do solo. Planta Daninha, v. 23, n. 1, p. 17-24, 2005.

SILVA, A. C.; HIRATA, E. K.; MONQUERO, P. A. Produção de palha e supressão de plantas daninhas por plantas de cobertura, no plantio direto do tomateiro. Pesq. Agropec. Bras., v. 44, n. 1, p. 22-28, 2009
STALL, W. M.; MORALES-PAYAN, J. P. The critical period of Nutsedge interference in tomato. Southwest Florida Research \& Education Center: University of Florida, 2003. Disponível em: <http://www.imok.ufl.edu/liv/ groups/IPM/weed_con/nutsedge.htm $>$ Acesso em: 10 mar 2009.

SUZUKI, L. E. A. S.; ALVES, M. C. Fitomassa de plantas de cobertura em diferentes sucessões de culturas e sistemas de cultivo. Bragantia, v. 66, n. 1, p. 121-127, 2006.

TALAVERA, M. E.; PADILLA, J. R. Evaluación de coberturas orgánicas y plásticas para el combate de malezas en tomate (Lycopersicon esculentum Miller). Agron.

Mesoamericana, v. 11, n. 2, p. 101-107, 2000.

TREZZI, M. M.; VIDAL, R. A. Potencial de utilização de cobertura vegetal de sorgo e milheto na supressão de plantas daninhas em condição de campo: II - Efeitos na cobertura morta. Planta Daninha, v. 22, n. 1, p. 1-10, 2004.

TSEKLEEV, G; BOYADJIEVA, N.; SOLAKOV, Y. Influence of photo-selective mulch films on tomatoes in greenhouses. Plasticulture, v. 95, n. 1, p. 45-49, 1993.

WAMSER, A. F.; MUELLER, S. Tomate: Direto na palha Cult. Hort. Frutas, n. 50, p. 6-7, 2008.

WEAVER, S. E. Critical period of weed competition in three vegetable crops in relation to management practices. Weed Res., v. 24, p. 317-325, 1984.

WEAVER, S. E.; SMITS, N.; TAN, C. S. Estimating yield losses of tomatoes (Lycopersicon esculentum) caused by nightshade (Solanum spp.) interference. Weed Sci., v. 35, p. 163-168, 1987.

WEAVER, S. E.; TAN, C. S. Critical period of weed interference in field-seeded tomatoes and its relation to water stress and shading. Can. J. Plant Sci., v. 67, n. 4, p. $575-583,1987$.

WEAVER, S. E.; TAN, C. S. Critical period of weed interference in transplanted tomatoes (Licopersicon esculentum): growth analysis. Weed Sci., v. 31, p. 476-481, 1983. 